\title{
IMPORTANCE AND NECESSITY OF INTERNATIONAL JUDICIAL COOPERATION IN CRIMINAL MATTERS
}

\author{
G. Modiga
}

\section{Georgeta Modiga}

Faculty of Law, "Danubius" University Galati, Romania

*Correspondence: Georgeta Modiga, "Danubius" University Galati, Galati St. Galati, Romania

E-mail: georgeta.modiga@yahoo.com

\section{Abstract}

After careful consideration, we can say that in evolution, human society was and is threatened by a number of factors that can be generally divided into internal, external and natural. Currently, it is difficult to assess which are the most dangerous threats to a community, requiring a rather complex analysis that ultimately will reveal that each threat as minor should be duly untreated immediate reaction in terms of society, can become a real threat as less than or greater. The unprecedented development of international relations in contemporary society has been accompanied by an increase also unprecedented, international crime, the proliferation of forms of organized crime in several states.

Keywords: measures of self-defence, crime, contemporary society

\section{Introduction}

Over time, the cooperation of the states was made on the basis of bilateral or multilateral legal instruments, resulting in agreements, conventions, treaties, etc. These legal instruments are of zone, regional or universal, according to the interests of the Parties, the magnitude and importance of the area addressed.

Concerns for international cooperation have existed since ancient times (particularly in the military and commercial), these developing and diversifying permanently, over time, according to the existing common interests at a time between different states.

A key element that led to the emergence and further development of international cooperation and without which it could not conceive, was the mutual trust in a well regulated institutional framework.

In this context, we define international cooperation as a means of mutual aid between different states, in different areas, specifically established by treaties, conventions, agreements and so on, ultimately aimed at promoting and protecting national interests, regional or world, based on the principle of the independence and sovereignty of each Contracting Party.

International judicial cooperation in criminal matters is just an area specific cooperative activity between states, extremely important area, which has become a necessity since the beginning of last century.

In its historical development, the company has constantly sought and found various ways of self defence, which did not represent anything other than immediate reactions to a number of dangers that threatened peace or even existence. Dangers faced by human society can certainly be considered, but only in the general context determined by the overall development of society it self.

Thus, some were dangers threatening peace or even the existence of a community during slavery, feudalism others and therefore more at this stage. Given the historical development of society, we find that these dangers are not identical; they are ultimately 
determined by a number of features specific to certain human communities, area, regional or global ${ }^{1}$.

After careful consideration, we can say that in evolution, human society was and is threatened by a number of factors that can be generally divided into internal, external and natural. Currently, it is difficult to assess which are the most dangerous threats to a community, requiring a rather complex analysis that ultimately will reveal that each threat as minor should be duly untreated immediate reaction in terms of society, can become a real threat as less than or greater. It is known that most of the times, the company responded by producing an event taking take a number of measures of self-defence or coercive.

The unprecedented development of international relations in contemporary society has been accompanied by an increase also unprecedented, international crime, the proliferation of forms of organized crime in several states.

Scientific and technical progress made, as well as enhancing the democratization process in several states created the possibility of movement of people and goods easily, thus leading to the development of human society as a whole. Unquestionably beneficial effect for the entire humanity, created some advantages for the wide proliferation of possibilities crime phenomena worldwide.

The growing threat caused by the growth of transnational crime, the need to prevent and combat more effectively in an organized worldwide led to the adoption of international instruments zone, regional and global efforts to unify the world states.

The United Nations Convention against Transnational Organized Crime, the Protocol to Prevent, Suppress and Punish Trafficking in Persons, especially Women and Children and the Protocol against the smuggling of migrants by land, air and sea (both additional to the Convention) adopted in New York on 15 November 2000, established a series of measures primarily aimed at international judicial cooperation in criminal matters in order to prevent and combat more effectively (through a joint effort of Member) organized transnational crime.

According to the Convention, " organized criminal group expression means a structured group of three or more persons, existing for a certain period of time and acting in concert with the aim of committing one or more serious crimes or offences under this Convention to get direct or indirectly a financial or other material benefit. "

To avoid a unilateral interpretation of the state or another, the Convention defines the crime of "transnational" as that offence "is committed in more than one State;

- Is committed in one State but a substantial part of its preparation, planning, direction or control takes place in another State;

- Is committed in one State but involves an organized criminal group that engages in criminal activities in more than one state or

- Is committed in one State but has substantial effects in another State".

A particular danger to the security of states is the unprecedented growth of organized crime in all its forms of manifestation.

The current phase of development of human society face other hazards models, much different from those known in earlier historical periods. The largest and important in this regard is the danger of terrorism.

About terrorism, although it is known in some form since ancient times, has been written and will write for a long time, as is currently the most dangerous manifestation of organized crime. Contemporary terrorism is the most advanced form of organization and action in the service of anarchist groups, often religious, with claims of mostly political ${ }^{2}$. An

\footnotetext{
${ }^{1}$ C. Bulai B., N. Bulai, Drept penal, Partea generala, Legal Universe Publishing House, Bucharest, 2007, p. 102 ;

2 R.M. Stănoiu, Asistenta juridica internationala in materie penala, Academy Publishing House, Bucharest 2003, p. 83;
} 
overall analysis of forms of international crime highlights first diversification methods of action, organization and logistics often perfect those involved in such events in the past 30-40 years, in addition to terrorism, they developed other forms of crime, namely trafficking and consumption of drugs, arms trafficking, human trafficking, human trafficking, trafficking for the purpose of immigration etc., criminal activity, even if not up to the dangers of terrorism, may be the subject of analysis and concern at the level of any state.

Accession to the European Union since January 2007 it involves a number of new obligations imposed by statute or by the Union, obligations mainly focused on the need to contribute to ensuring a European area of freedom, security and justice to the highest standards.

In this context, Romania became EU border country with the mission to ensure the external border of the EU Member illegal immigration, trafficking in weapons, ammunition, drugs, radioactive substances, etc..

Schengen enlargement will create new facilities for easy movement without risk of criminal elements from corner to corner of Europe.

An absolute must is the improvement of the legislative framework aimed at criminalizing the threat of new acts committed in different villages States.

Harmonization criminalization of acts of danger and discovery procedures, research and trial in the Member States, will allow the best conditions of safety climate civic.

The most important aspect in preventing and combating crime is the intensification and improvement of specific activities to identify, catch and prosecuting the perpetrators of criminal acts.

It is known that all persons who have committed criminal trying to evade liability established by law, adopting different strategies increasingly sophisticated, stretching from corrupt members of institutions of law enforcement officials to hide the in other states.

Legislative and procedural measures taken in the execution of laws must be consistent with the rights and fundamental freedoms enshrined in international instruments and the European Union.

The unprecedented development of human society as a whole in the twentieth century paved the permanent developments in line with the new achievements of science in the field of crime unwanted.

In this context, emerged the growing crime increased, reaching peak by improving complex forms of manifestation of organized crime, namely terrorism, manufacture, trafficking and abuse of drugs, human trafficking, trafficking weapons and ammunition, counterfeit currency or other valuables, etc.

In recent years, these complex forms of manifestation of crime have crossed the borders of a single state, manifesting itself in most situations in several countries or continents. Although quite heavy, world states known democracies understood, however, that the only way to achieve a better control under preventive aspect (the phenomenon itself) is related to the implementation of the relevant international judicial cooperation.

Organized crime currently has the ability to create great economic and political tensions, causing even the failure of governments, where managed to get in the leading political parties in coalition ${ }^{3}$.

Criminal organizations take full advantage of the sharp rise in international tourism, a certain relaxation of migration policy liberalization, free trade expansion, advanced communication equipment and not least money laundering technique to realize and protect goals. A circulation facility to citizens within the European Union, especially in the Schengen area, creates other advantages criminal organizations.

\footnotetext{
${ }^{3}$ Pocora Monica, Special seizure Stipulated in Romanian Criminal Law and Special Law, Lambert Academic Publishing House, Germany 2011, p. 28;
} 
Moreover, due to difficulties experienced by the economies of many countries, in particular those in developing criminal organizations were directly involved in the processes of privatization, buying some companies sold some governments trying in this way to restart economies after long periods of national crisis. The purchase of state owned banks, manufacturing companies, telecommunications service or have served them as a shield covering their clandestine operations, while helping to increase power and influence in the contemporary world ${ }^{4}$.

Crime Developed and always growing so- called "white-collar" is a particular danger, always topical for the rule of law, as the heads of these structures have economic and political power to change certain decisions of governments to their advantage.

Currently and in the future, the most serious threat to human existence is the resurgence of international terrorism which has reached an unprecedented scale, often affecting safety states, destabilizing national economies, organizations and institutions, implications on the civilian population panic, scared and outraged by the cruel and despicable means used by terrorists.

The bloody events in recent years, culminating blow to U.S. 11 September 2001 by members of the terrorist network " Al- Qaeda ", led by billionaire Osama bin- Laden (considered liable and bomb attacks on American embassies in Kenya and Tanzania on August 7, 1998) are appalled and aware while all humanity, in the same context enrol terrorist attacks in Russia, Spain, England, Italy and Japan, resulting in significant casualties and property damage.

Hijacking of aircraft attacks bacteriological substances, bomb attacks on trains or subways, suicide bombings are just some of the tools and sites used by terrorists in recent years.

The presence and proliferation of international concern crime caused a response of solidarity from the States, making them aware of the need to intensify cooperation in identifying specific activities, catch, arrest and conviction of the guilty.

The ultimate goal of the work of judicial cooperation between different countries is to achieve a reduction to acceptable levels of crime and hence more safety of its citizens.

The main problem that arises in the current acceleration of the globalization process is to coordinate national policies and strategies with the strategies, policies and regulations stated and accepted internationally.

In recent years, international judicial cooperation has seen new and diverse forms, some domestic legal rules enacted by other specified in various international treaties and conventions. Specialists in the field have made the definition of international judicial cooperation, the institution appeared and manifested only quite active lately due to mutations that occurred in the activity of criminal organizations and the need to prevent and reduce crime generated.

We appreciate that this institution can be defined broadly or narrowly, against the rather complex issue addressed.

Thus, broadly, the international judicial cooperation can understand that form of cooperation aimed at complex activities that world governments in order to reduce crime and increase safety of their citizens, working together, with and help each other to achieve specific activities that: extradition, surrender under a European arrest warrant, transfer of proceedings in criminal matters and the recognition and enforcement of judgments, transfer of sentenced persons, mutual legal assistance in criminal matters or similar forms or rules established by the laws, treaties, agreements, conventions or reciprocity.

\footnotetext{
${ }^{4}$ Pocora Monica, General Aspects regarding the particular seizure in Romanian Legislation, Lambert Academic Publishing House, Germany 2011, p. 15;
} 
Narrow by international judicial cooperation means a specific way of action by world governments and unions act granting the forms established by law, agreements, treaties, conventions, in order to trap, proving criminal activity and punish perpetrators of acts proceedings and of the reduction of crime.

The best known form of judicial cooperation in criminal matters is arguably extradition, there is a certain period in the Romanian law was the only one. Referring to the above provisions of the Criminal Code Charles II is estimated that: the old Romanian criminal enactment contained no provision governing extradition. Article 32 of Constitution 1923 (was 30 in The Constitution of 1866) provides only that "the extradition of political refugees is stopped." Also in art. 6 of the Act of June 9, 1886 regarding the abolition of the State Council shall provide that extradition decided by the Council of Ministers, after a preliminary inquiry.

These were the only devices until the coming of the new Criminal Code Charles II. Therefore, pending criminal Code Charles II there were no provisions governing judicial cooperation, even for extradition. Nevertheless, Romania, during the end of the twelfth century and beginning of the twentieth century, numerous conventions concluded extradition.

We see, therefore, a particular concern in forms quite shy, but safe for international judicial cooperation between the Romanian state and other states since that time.

But I must mention that the institution of extradition, as the only known form of judicial cooperation, extradition did not allow Romanian citizens, such provisions appearing in both the international conventions ratified by Romania and in other international instruments of this kind. Carol Criminal Code II provides a number of legal rules on extradition, which is the main form of international judicial cooperation in criminal matters recognized. To remember is that these rules, except the provisions prohibiting extradition of Romanian citizens and political refugees, are so complete that some may be outdated even today.

Regarding the substance of extradition, criminal law rules provide that they are "the established international conventions, and their lack of reciprocity exists and the provisions of this section".

As we can see, in the Criminal Code are not provided other forms of international judicial cooperation in criminal matters.

During the communist dictatorship, according to treaties and conventions ratified by Romania, with the statements of reciprocity bilateral forms of cooperation have diversified, but the most important remaining extradition.

We split therefore from this point of view, forms of criminal assistance in accordance with the purpose (which the offence in general) and forms the criminal procedure (relating to a specific crime) outside these circular forms and procedural information meeting according to the first classification mentioned above, both religious forms and forms possibly acceptable.

In the literature, it was shown that there are part of the religious forms which have as their object the purchase of information, therefore, informative forms: submission of copies of or extracts from criminal judgments, remittance slips criminal record and, finally, the exchange international information on a range of issues of interest to states in their fight common crime count.

Other complementary forms aimed at special immunities which immunity from prosecution and arrest of witnesses who come to the country for offences committed by them before being present in the country. Of course, this immunity does not operate when the witness in question commit criminal acts, after coming into the country and not leave Romania in a certain period. Another form complementary refers to the operation thereof. Thus, proof of service of the summons or the finding of impossibility of dispatch, the requested State shall be transmitted. When submitting a prisoner is held under certain agreements, it may be subject to certain conditions laid down in the Treaties or Conventions. 
Effects of handing a prisoner for the purpose of hearing or confrontation are limited to a witness in the cause for which it was submitted. Therefore, the applicant may not proceed to any other act, apart from hearing or submitted in person confrontation because, for which remission was sought, the requested State may agree, however, under certain conditions, the performance and other acts against the person submitted.

\section{Conclusions}

1. Another form of cooperation with procedural character is sending pieces form, in which any State may, even in the absence of any agreement, to send to another state record that are in possession of the parts to which it is required by another state four solving a case.

2. Literature included in the activity are procedural character and work through the Interpol police cooperation, relying on the fact that this organization performs specific activities tracking, identification and arrest of persons wanted by law in connection with the suspicious, it is stated: " but the predominant activity that aims to identify and arrest some criminals exposures sat on this form under the criminal procedure forms."

3. Cooperation about letters rogatory is another form of international cooperation with the criminal procedure, which is conducted at the request of interested state unit. Discovering crime and identify authors is only the first step in the work of international legal assistance.

\section{Bibliography}

Pocora Monica, Special seizure Stipulated in Romanian Criminal Law and Special Law”, Lambert Academic Publishing House, Germany, 2011;

Pocora Monica, General Aspects regarding the particular seizure in Romanian Legislation, Lambert Academic Publishing House, Germany, 2011;

C. Bulai, B.N. Bulai, Drept penal, Partea generala, Universe Legal Publishing House, Bucharest, 2007;

R.M. Stănoiu, Asistenta juridica internationala in materie penala, Academy Publishing House, Bucharest, 2003. 